\title{
EFEK DENTOSKELETAL PADA MALOKLUSI KELAS II DIVISI 1 DENGAN BIONATOR DAN ALAT ORTODONTI LEPASAN : LAPORAN KASUS
}

Sari Kurniawati*, Angela Putri Bunga ${ }^{* *}$

\begin{tabular}{c}
\hline Keywords: \\
Class II division \\
1 malocclusion, \\
Protrusive, \\
Mandibular \\
retrognation, Bionator
\end{tabular}

\begin{abstract}
Background: Class II division 1 malocclusion characterized by mandibular retrognation, deep bite and increasement of overjet. Myofunctional appliance could modify the growth and developmental of mandibular at appropriate phase. The purpose of this case report was to present successful management of Class II division 1 by using bionator and removable appliance.
\end{abstract}

Case Management: A 9 years old girl with upper teeth protrusion, crowding and affected the esthetical perception. The diagnosis was Class II division 1 with mandibular retrognation and upper incisor protrusion, upper and lower anterior crowding and palatal bite. Patient also had lip biting and thumb sucking habit. Bionator leads the mandibular moved forward and arch widening. Treatment planning were to reduce overjet by prognating mandibular and bad habit elimination. Followed by retracting the upper teeth and deep bite correction by using removable appliance.

Conclusion: Patient profile became corrected in 10 weeks. Overjet reduced in by prognating the mandible, decreasing of palatal bite, molar relation become Class I and bad habit elimination. In 10 months, overjet and overbite were corrected.

\section{PENDAHULUAN}

Maloklusi adalah oklusi yang menyimpang dari keadaan normal, terdapat ketidakteraturan gigi atau lengkung gigi di luar rentang normal. Maloklusi juga dapat menyebabkan terjadinya masalah periodontal, gangguan fungsi lisan, gangguan pengunyahan, cara menelan yang salah, masalah bicara dan psikososial yang berkaitan dengan estetika ${ }^{1}$.

Maloklusi merupakan masalah gigi yang paling umum terjadi, sehingga pasien memiliki keinginan untuk melakukan tindakan perawatan ortodontik ${ }^{1}$. Tujuan perawatan ortodontik adalah untuk memperbaiki susunan gigi-geligi dan hubungan rahang yang tidak normal sehingga dapat tercapai oklusi, fungsi yang normal, estetis wajah yang baik ${ }^{2}$, memperoleh keharmonisan bentuk muka, relasi dan fungsi pengunyahan yang baik, serta stabilitas hasil akhir ${ }^{3}$.
Salah satu kondisi maloklusi yang paling sering terjadi adalah adanya protrusi anterior atas disertai dengan berdesakan pada regio anterior atas dan bawah. Hal tersebut menyulitkan pasien dalam menjaga kebersihan mulutnya karena saat menyikat gigi, sikat gigi sulit menjangkau sisa makanan yang menempel di area interdental sehingga terjadi akumulasi plak dan membentuk kalkulus kemudian menjadi pemicu terjadinya gigi berlubang (karies) dan penyakit gusi (gingivitis) bahkan dapat terjadi kerusakan jaringan pendukung gigi (periodontitis $)^{4}$.

Overjet yang sangat besar dikarenakan proklinasi insisivus atas dan mandibula yang retrognati dapat membuat tampilan bibir pasien tampak seperti inkompeten dan membuat pasien merasa tidak percaya diri akan penampilannya.

Beberapa alat myofungsional yang berguna untuk mengoreksi diskrepansi skeletal, bentuk

** Fakultas Kedokteran Gigi Universitas Brawijaya

Korespondensi: sarikurniawati@ub.ac.id 
lengkung rahang dan fungsi orofasial salah satunya adalah Bionator ${ }^{5,6}$. Bionator dapat mengoreksi diskrepansi yang terjadi pada dentoalveolar dan skeletal. Perubahan dentoalveolar terjadi akibat retraksi dan uprigting insisivus maksila diikuti oleh proklinasi gigi insisivus bawah. Meskipun tidak ada perubahan skeletal pada maksila, peningkatan panjang mandibula juga terjadi pada pasien yang menggunakan bionator. Perubahan skeletal yang signifikan berpengaruh terhadap perubahan jaringan lunak, terutama dimensi vertikal wajah dan posisi bibir $7,8,9$.

Tujuan dari laporan kasus ini adalah memaparkan perawatan menggunakan bionator pada pasien dengan maloklusi Angle kelas II divisi 1 dengan pola skeletal kelas II, disertai retrognati mandibula dan protrusi insisivus atas. Publikasi kasus ini telah mendapat persetujuan dari orang tua pasien bagi kepentingan ilmu pengetahuan.

\section{LAPORAN KASUS}

Seorang pasien perempuan berumur 9 tahun datang ke klinik Ortodonsia Rumah Sakit Pendidikan Universitas Brawijaya Malang dengan keluhan gigi depan atas maju sehingga mengganggu penampilan. Hasil pemeriksaan ekstra oral menunjukkan bentuk kepala mesosefali, bentuk muka mesoprosop, profil muka cembung, sendi temporo mandibular normal, bentuk muka asimetris, dan bibir posisi istirahat kompeten. Pemeriksaan intra oral menunjukkan Oral Hygiene Index baik, ukuran lidah normal dan tinggi palatum dalam. Gigi-geligi dalam fase gigi-geligi pergantian, semua molar satu permanen telah erupsi sempurna. Pada saat oklusi sentrik, overjet 11 $\mathrm{mm}$, overbite $5 \mathrm{~mm}$, terdapat palatal bite, dan relasi molar kelas II (relasi molar dua desidui flush terminal plane dan relasi molar permanen cusp-to-cusp). Palatal bite terjadi karena supraklusi gigi anterior (berdasarkan analisis Thompson-Brodie).

Berdasarkan hasil orthopantomograph menunjukkan adanya benih pada semua gigi permanen yang belum erupsi dan jaringan periodontal tidak ada kelainan. Analisis sefalometri didapatkan hasil bahwa hubungan skeletal klas II dengan proklinasi insisivus atas. Diagnosis kasus ini adalah maloklusi Angle kelas II divisi 1, pola skeletal kelas II dengan retrognati mandibula disertai protrusi anterior atas, berdesakan anterior atas dan bawah, serta palatal bite. Kebiasaan buruk pasien adalah menggigit bibir atas dan bawah dari usia 3 tahun hingga 8 tahun, frekuensi jarang namun intensitasnya kuat. Mengisap ibu jari juga dilakukan hingga usia 2 tahun, frekuensi jarang, namun intensitasnya kuat. Prognosis kasus ini baik karena pasien didukung oleh jaringan pendukung gigi yang baik, usia pasien masih muda, motivasi tinggi, status ekonomi baik, kerjasama pasien baik serta kondisi kesehatan pasien juga baik.

Perhitungan diskrepansi dan kesimpulan analisis sefalometri didapatkan rencana perawatan kasus sebagai berikut: 1) tahap instruksi operator kepada pasien mengenai perawatan ortodontik, 2) tahap perawatan dengan alat fungsional Bionator dan dilanjutkan perawatan dengan peranti ortodontik lepasan (evaluasi dan observasi hasil dari tahap I, 3) pemakaian retainer.

Perawatan tahap I adalah operator memberikan penjelasan kepada pasien tentang perawatan ortodontik, mengenai prosedur perawatan, cara perawatan, lama perawatan, cara memakai dan melepas alat, dan pasien diminta untuk menjaga kebersihan mulutnya serta menghilangkan kebiasaan buruknya 
seperti menggigit bibir atas dan bawah agar tidak menghambat perawatan ortodontik.

Perawatan tahap II dilakukan pemakaian alat fungsional Bionator untuk memajukan mandibula dan mengoreksi palatal bite. Pertama memajukan mandibula sebesar $2 \mathrm{~mm}$ kemudian dievaluasi. Saat pembuatan gigitan kerja untuk pembuatan Bionator, mandibula dimajukan $4 \mathrm{~mm}$ untuk mengurangi risiko apabila terjadi relaps. Evaluasi dan observasi dilakukan sebelum dilanjutkan dengan peranti lepasan. Alat bionator terdiri atas: a) Alat rahang atas dan rahang bawah yang bersatu, b) Gigitan anterior dengan bite plane pada gigi rahang bawah, c) Gigitan posterior dibebaskan, d) Lengkung labial (maxillary guide wire) dari interdental gigi kaninus rahang atas dengan diameter 0,8 mm, e) Sekrup ekspansi pada rahang bawah (gambar 1).

Bionator tidak digunakan hanya ketika makan dan minum, menyikat gigi atau membersihkan alat dan sewaktu berolahraga. Pada minggu pertama, alat digunakan selama beberapa jam setiap harinya. Pada periode ini dianjurkan untuk berlatih berbicara ketika keadaan masih menggunakan alat di dalam mulut.

Pada minggu kedua, Bionator digunakan selama aktivitas di dalam rumah. Minggu ketiga, alat digunakan ketika bersekolah dan selama di rumah. Minggu keempat, alat digunakan sepanjang hari dan ketika tidur. Namun, untuk mempercepat kemajuan perawatan, pasien sejak minggu kedua sudah menggunakan Bi- onator sepanjang hari dan ketika tidur.

Perawatan dengan alat ini dianggap selesai jika overjet berkurang minimal $2 \mathrm{~mm}$ dan tidak relapse. Kontrol dilakukan seminggu sekali. Pada minggu pertama, belum dilakukan pengurangan plat akrilik dan penyesuaian gigitan dengan tujuan agar pasien beradaptasi dahulu dengan alat yang dipakai. Setelah dilakukan perawatan myofungsional, dilakukan pencetakan model gigi sebagai panduan perencanaan tahapan perawatan dengan peranti lepasan.

Selama kontrol, sekrup ekspansi rahang bawah diaktifkan secara berkala sebesar $1 \times 1 / 4$ putaran setiap minggu sampai mendapatkan ruangan sebesar $4 \mathrm{~mm}$ ke lateral. Hal tersebut bertujuan untuk koreksi oklusi sekaligus pencarian ruang untuk koreksi malposisi gigi individual.

Pengurangan plat juga dilakukan setiap kontrol pada bagian oklusal dan distal gigi-geligi rahang atas, serta bagian oklusal dan mesial untuk gigi-geligi rahang bawah sebesar $1 \mathrm{~mm}$.

Setelah penggunaan Bionator selesai, dilanjutkan dengan penggunaan alat ortodontik lepasan untuk koreksi overjet dengan retraksi anterior atas, protraksi anterior bawah dan koreksi overbite dengan peninggian gigi anterior.

Hasil perawatan setelah 10 minggu menggunakan Bionator didapatkan pengurangan overjet sebesar $4 \mathrm{~mm}$ (over correction), pengurangan overbite sebesar $0,5 \mathrm{~mm}$, relasi molar satu permanen menjadi kelas I. Kebiasaan

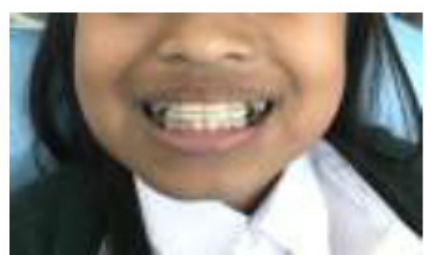

(a)

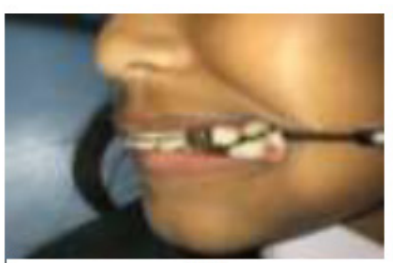

(b)

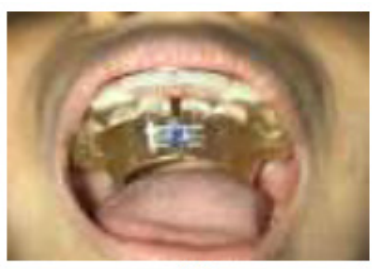

(c)

Gambar 1. Bionator yang dipakai oleh pasien. (a) Tampak depan; (b) Tampak samping; (c) Tampak oklulsal 


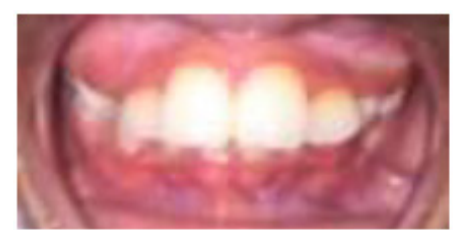

(a)

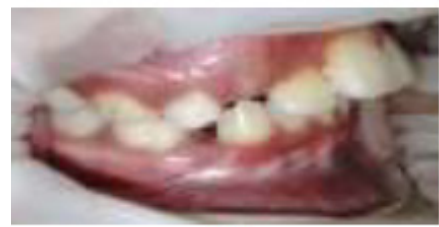

(d)

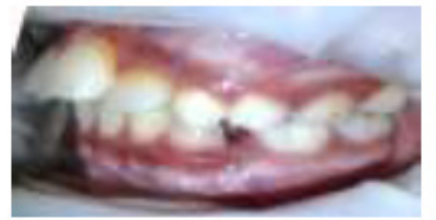

(g)

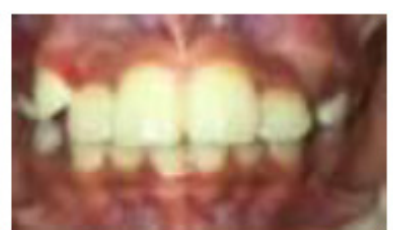

(b)

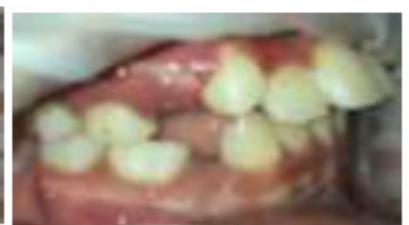

(e)

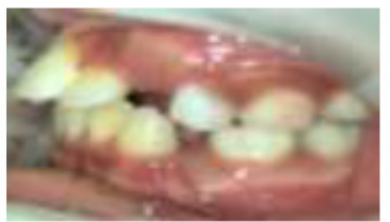

(h)

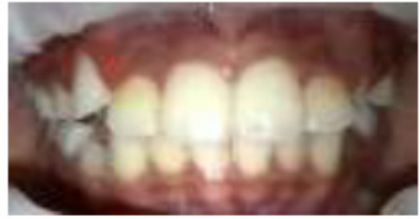

(c)

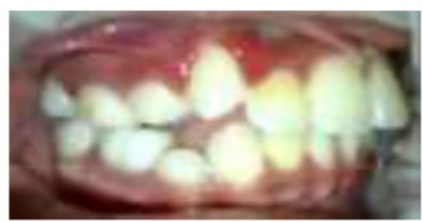

(f)

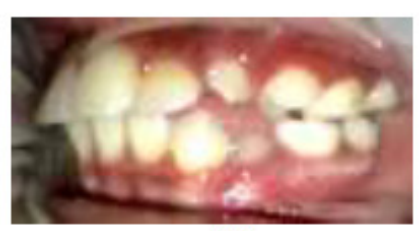

(i)

Gambar 2. Foto Intra Oral. (a) Tampak depan sebelum perawatan; (b) Tampak depan setelah perawatan Bionator; (c) Tampak depan setelah perawatan Alat Ortodonti Lepasan; (d) Samping kanan sebelum perawatan (e) Samping kanan setelah perawatan Bionator; (f) ) Samping kanan setelah perawatan Alat Ortodonti Lepasan; (g) Samping kiri sebelum perawatan; (h) Samping kiri setelah perawatan Bionator; (i) Samping kiri setelah perawatan Alat Ortodonti Lepasan

buruk pasien juga telah hilang (gambar 2).

Setelah pemakainan Bionator, perawatan dilanjutkan dengan alat ortodontik lepasan dengan tujuan perbaikan profil wajah pasien dengan pengurangan overjet sebesar $7 \mathrm{~mm}$, pengurangan overbite sebesar $2,5 \mathrm{~mm}$ dan koreksi malposisi gigi individual.

Setelah 10 bulan didapatkan pengurangan overjet sebesar $1,5 \mathrm{~mm}$, pengurangan overbite sebesar $1 \mathrm{~mm}$, sehingga didapatkan overjet $5,5 \mathrm{~mm}$ dan overbite $3,5 \mathrm{~mm}$. Tampak perubahan profil wajah pasien yang cukup signifikan (gambar 3). Perawatan masih berlangsung hingga didapatkan overjet dan overbite yang normal, yaitu masing-masing $2 \mathrm{~mm}$.

\section{DISKUSI}

Kasus Maloklusi Angle kelas II divisi 1 dengan retrognati mandibula, protrusi insisivus atas, palatal bite, malposisi gigi individual, den- gan kebiasaan buruk menggigit bibir bawah dan menghisap ibu jari telah dirawat selama 10 minggu. Etiologi maloklusi Angle kelas II divisi 1 ini disebabkan oleh kehilangan prematur gigi kaninus atas dan bawah serta diperparah dengan kebiasaan buruk.

Retrognati mandibula menyebabkan penampilan tidak estetis dan pasien merasa malu. Usia pasien yang masih 9 tahun memungkinkan terjadinya modifikasi pertumbuhan mandibula karena masih dalam fase tumbuh kembang. Usianya yang akan masuk dalam rentang waktu growth spurt dan pasien yang sangat kooperatif juga turut meningkatkan prognosis hasil perawatan. Salah satu alat myofungsional yang mampu mengarahkan mandibula ke arah anterior adalah Bionator.

Bionator merupakan alat untuk mengoreksi gigitan menggunakan tekanan otot pengunyahan dengan desain untuk memajukan mandibula secara langsung dan dengan pemakaian 
sepanjang hari, gigi lebih cepat bergerak, gigitan meningkat dan relasi molar menjadi normal. Bionator bekerja pada otot pengunyahan dengan cara: (1) menggigit-gigitkan gigi pada alat, (2) mengaktifkan otot saat bicara, dan (3) mengaktifkan otot saat tersenyum ${ }^{5,6}$. Perubahan tersebut terlihat pada pasien setelah 10 minggu.

Hasil dari pemeriksaan yang didukung dengan analisis lokal, model studi dan sefalometri serta adanya faktor tumbuh kembang menunjukkan bahwa bionator berhasil menuntun rahang bawah untuk bergerak ke anterior dan memperlebar lengkung rahang. Hal tersebut terjadi karena lidah secara konstan dipandu oleh maxillary guide wire sehingga membantu membawa rahang ke posisi yang benar. Bionator juga membantu menghilangkan kebiasaan pasien menggigit bibir bawah dan menghisap ibu jari karena desain atas dan bawahnya yang menyatu mampu menahan otot labial untuk tidak mudah tergigit dan menahan keinginan pasien untuk menghisap ibu jari.

Hasil perhitungan diskrepansi pada model studi selama 10 minggu menunjukkan perubahan-perubahan yang cukup signifikan. Over-

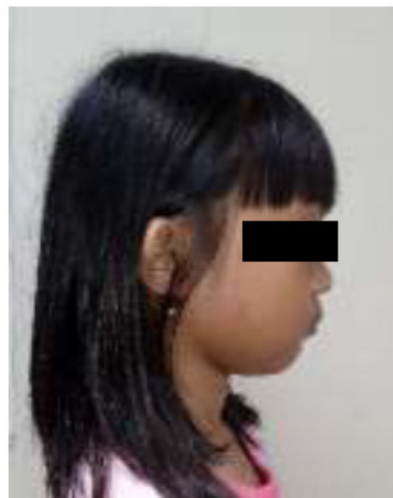

(a)

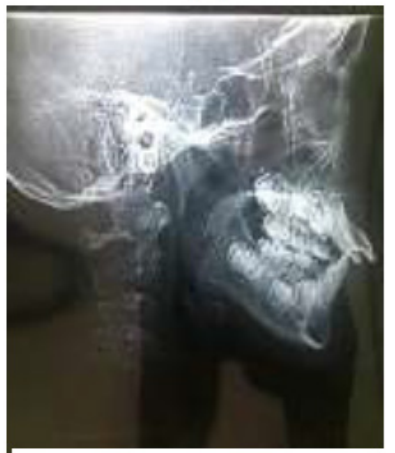

(c)

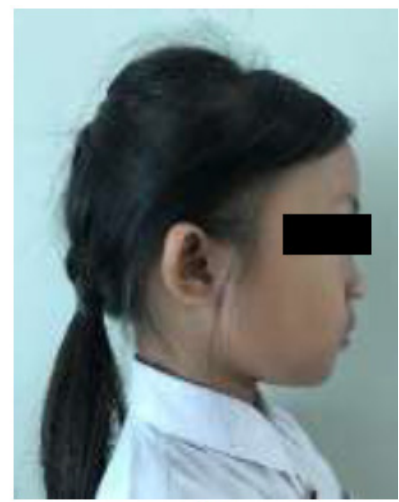

(b)

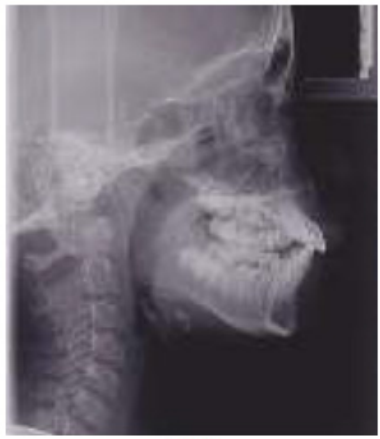

(d)

Gambar 3. Foto Profil dan Sefalograf. (a) Tampak Samping Sebelum Perawatan; (b) Tampak Samping Setelah Perawatan; (c) Sefalometri Sebelum Perawatan; (d) Sefalometri Sebelum Setelah Perawatan

Tabel 1. Analisis sefalometri sebelum dan setelahperawatan

\begin{tabular}{cccc}
\hline Pengukuran & $\begin{array}{c}\text { Nilai } \\
\text { Normal }\end{array}$ & $\begin{array}{c}\text { Sebelum } \\
\text { Perawatan }\end{array}$ & $\begin{array}{c}\text { Setelah } \\
\text { Perawatan }\end{array}$ \\
\hline SNA & $82^{\circ}( \pm 3)$ & $78.5^{\circ}$ & $79.5^{\circ}$ \\
SNB & $80^{\circ}( \pm 3)$ & $74^{\circ}$ & $75^{\circ}$ \\
ANB & $2^{0}( \pm 2)$ & $4.5^{\circ}$ & $3.5^{\circ}$ \\
U1-SN & $103^{\circ}( \pm 5)$ & $124^{\circ}$ & $107^{\circ}$ \\
L1-GoMe & $93^{\circ}( \pm 7)$ & $93^{\circ}$ & $94^{\circ}$ \\
\hline
\end{tabular}


jet menjadi $7 \mathrm{~mm}$, overbite menjadi $4,5 \mathrm{~mm}$, dan relasi molar satu permanen menjadi kelas I. Hal ini diperkuat dengan perubahan sudut SNB sebesar $1^{\circ}$ dan pola skeletal menjadi kelas II (tabel 1).

Perubahan relasi molar menjadi kelas I dan pergerakan mandibula ke anterior dipengaruhi oleh pergerakan gigi-geligi molar rahang bawah ke arah anterior sesuai pengurangan plat bagian mesial pada oklusal posterior bawah dan adanya peninggian gigit pada anterior bawah. Adanya pembebasan oklusi gigi-geligi posterior tersebut mempercepat perubahan.

Perawatan selanjutnya untuk koreksi overjet dilakukan dengan aktivasi busur labial untuk retraksi anterior atas. Retraksi anterior yang terjadi akibat gerakan tipping menyebabkan perubahan bermakna yang cukup besar pada perubahan sudut inklinasi insisivus atas sebesar $17^{\circ}$ (tabel 1$)$.

Penggunaan ekspansi sagital untuk protraksi anterior bawah juga menyebabkan perubahan pada inklinasi insisivus bawah sebesar $1^{\circ}$ (tabel 1 ) sehingga overjet berkurang menjadi $5,5 \mathrm{~mm}$.

Tujuan kedua adalah koreksi palatal bite. Berdasarkan pemeriksaan Thompson-Brodie test didapatkan hasil bahwa etiologi deep bite diakibatkan adanya supraklusi gigi anterior, sehingga diberikan peninggian gigit anterior yang berfungsi untuk mengintrusi gigi-geligi anterior bawah. Komponen ini efektif mengurangi overbite sebesar $1 \mathrm{~mm}$ sehingga didapatkan overbite yang normal.

Alat ekspansi sagital pada rahang bawah yang berfungsi untuk mengurangi overjet, kemungkinan juga berdampak terhadap adanya pengurangan overbite. Saat pergerakan intrusi gigi, secara biomekanik gaya harus melewati centre of resistance sehingga gerakan translasi dapat terjadi tanpa adanya tipping. Semakin jauh titik gaya yang diaplikasikan dari centre of resistance, maka dapat menyebabkan momen rotasi yang semakin besar, sehingga flaring gigi insisivus lebih mungkin terjadi, khususnya pada kelas II divisi $1^{10}$.

Dapat disimpulkan bahwa pengurangan overbite terjadi akibat intrusi sekaligus adanya flaring dari gigi-geligi anterior bawah. Hal ini terlihat dari nilai L1-GoMe yang bertambah setelah perawatan yang berarti terdapat proklinasi insisivus bawah setelah perawatan

Perawatan masih dilakukan dengan menggunakan alat ortodonti lepasan untuk melanjutkan koreksi overjet, overbite dan malposisi gigi individual.

\section{KESIMPULAN}

Maloklusi kelas II divisi 1 Angle dengan retrognati mandibula dan protrusi insisivus atas pada masa pertumbuhan dan perkembangan dapat dirawat secara dini dengan menggunakan alat fungsional Bionator dan dilanjutkan dengan alat ortodonti lepasan. Hasil perawatan cukup baik dengan tercapainya overjet $5,5 \mathrm{~mm}$, overbite $3,5 \mathrm{~mm}$, relasi molar satu permanen menjadi kelas I, perubahan profil muka pasien dan hilangnya kebiasaan buruk menggigit bibir dan menghisap ibu jari. Kerja sama, kesabaran dan motivasi yang tinggi antara operator, orang tua dan pasien diperlukan untuk menunjang keberhasilan perawatan ortodontik lepasan.

\section{UCAPAN TERIMAKASIH}

Terima kasih kami ucapkan kepada tim Departemen Ortodonsia, Fakultas Kedokteran Gigi, Universitas Brawijaya. 


\section{DAFTAR PUSTAKA}

1. Graber, TM, Swain, BF. Orthodontic Current Principles and Techniques. 5th edition. The C.V. Mosby Company: St.Louis; 2011; 56-64, 169-73.

2. Pambudi-Rahardjo. Ortodontik Dasar. Airlangga University Press: Surabaya; 2009; 2-6, 60-79.

3. Profit WR, Fields HW, Sarver DM. Contemporary Orthodontics. 5th ed. Mosby Year Book: St.Louis; 2012 ; $248-53$

4. Luthfianty AP, Suparwitri S, Hardjono S. Perawatan Maloklusi Klas II Dlvisi 1 Dentoskeletal Disertai Retrusi Mandibula dengan Alat Fungsional Bionator. Maj Ked Gi. Desember 2014; 21(2): 212-216.

5. Almeida MR., Henriques JFC, Almeida RR, Almeida-Pedrin RR, Ursi W. Treatment Effects Produced by The Bionator Appliance. Comparison with An Untreated Class II Sample. Eur J Orthod. 2004 Feb;26(1):65-72.

6. Almeida MR, Henriques JFC, Ursi W. Comparative Study of Frankel (FR-2) and Bionator Appliance in The Treatment of Class II Malocclusion. Am J Orthod Dentofacial Orthop. 2002 May;121(5):458-66

7. Bolmgren GA, Moshiri F. Bionator Treatment in Class II Division 1. Angle Orthod. 1986; Jul;56(3):255-62.
8. Mamadras AH, Allen LP. Mandibular Response to Orthodontic Treatment with The Bionator Appliance. Am J Orthod Dentofac Orthop 1990; 97 : 113-20.

9. Illing HM, Morris DO, Lee RT. A Prospective Evaluation of Bass, Bionator, and Twin Block Appliances. Part I - The Hard Tissues. Eur J Orthod, 1998; 20: 501-16.

10. Daokar S, Agrawal G. Deep Bite Its Etiology, Diagnosis and Management: A Review. J Orthod Endod. 2016, 2:4. 